\title{
FINDING APPROPRIATED PRACTICE OF THE PILGRIMAGE SPACE: Ideological Contestation on the Sacred Site in Surowiti Gresik, East Java
}

\section{Taufiqurrohim}

Islamic State Institute of Tulungagung

Email: taufiqurrohim@mail.ugm.ac.id

\begin{abstract}
This paper examines how pesugihan (seeking wealth through spirit assistance) contests with pilgrimage discourse ideologically. In specific, to trace more about the grounds of the rise of contrary assumption of the pesugihan, this study focusses on how the ideological view, as the essential thinking of people, develops identity, practice, and its spirituality matter. The identity is constructed from the single view in responding to the phenomena and creating a sameness of collective joy created into the group, as Edith Turner examines about communitas and false communitas to see how the contestation is crystallized. Furthermore, this paper reviews the various pilgrimage practices to see how the communitas applied what they believe in the context of the pilgrimage. Lastly, it discusses how the visitors find their spirituality on pilgrimage, to see the reconciliation of the communitas conflict through gaze in visiting the pesugihan site. The paper argues that pesugihan is contested due to the contrary assumption of the practice rather than to see it as being religious with the traditional matter of context.
\end{abstract}

Keywords: pesugihan, ideological contestation, pilgrimage, mystical tradition

DOI: https://doi.org/10.20414/ujis.v23i2.352

\section{Introduction}

THE PRACTICE of pesugihan, or seeking spirit's assistance to gain wealth, seems to be odd in the present time. This perception cannot be separated from the assumption about the practice, not only for people who practice pesugihan, but also for the place that 
is used for it. In Gresik, ${ }^{1}$ a northern east coastal town of East Java, there is a pesugihan site called Surowiti hill. Despite this, Gresik in general and the location of pesugihan in particular is also famous as the city of santri and industry. A number of Islamic boarding schools and industrial communities are found here. It is therefore interesting to explore this unique site amidst rising modernization and Islamization.

People come to the hill to practice pesugihan to get wealth through praying at a sacred tomb or performing a specific ritual. Debates on the practices on the site are certainly a compelling case to explore since it will rise a contest between what practice should be done in a place that is considered pesugihan along with various kinds of identities carried by the visitors of the site or managers of this place. Thus, it is interesting to see how identity contestation takes place on this site. This study aims to examine how the identity of a community is formed and what identities are brought by the visitors. It also analyzes how the contestation occurs in interactions between communities that attempt to conceptualize what the concept of the pilgrimage is.

\section{Identicalness contestation of the community}

To see the foreground and the background of the communitas, it may be helpful to understand how the ideology is created by its relation. Goodman explains that the background of the community comes from what is physically planted on the ground, while its foreground raises from the human activity which has intimate relation among one and the others. It can be analogized on the case of the place where people do meditation and pilgrims. There is a step before it is constructed which start from the historical background of the dogma and its society, the contestation over it and the result of such contestation and development on it. $^{2}$ Mecca, as the destination for pilgrimage, has a historical background that can be imagined when people come to the place. The history of Abraham, who sought water for his son, Ismail, is imagined when

\footnotetext{
${ }^{1}$ A regency located in East Java province

2 Paul Goodman and Percival Goodman, Communitas: Means of Livelihood and Ways of Life (New York: Random House Vintage Book, 1960).
} 
Muslims make the pilgrimage. The other well-known histories written in Islamic text are the story of the elephant attacking $K a^{\prime} b a h .^{3}$ This becomes the other imagined-history that will be remembered by the visitors. It is told that the grandfather of the Prophet Muhammad defended $K a^{\prime} b a h$ with the help of the mystical bird and the history of the destruction of paganist statue surrounded black stone to change with the religious tradition is as the other foreground that can be considered.

The history points out how the contestation on the pilgrimage also happen in the place. It occurred in the prophetic era before the religion was constitutionalized, including before the Islamic teaching brought by the Prophet Muhammad. The belief is centred on the sacred text, and what is articulated of the texts by Muslims, meanwhile the development of the belief comes from the contextualization of the religious literature. This differs from paganism, which is more grounded in its interpretation of the belief imagined into a statue or the imagined concept of the universalism. So, their constructed faiths make a difference to see how the space between the command of the doctrine and their pack of spiritual belief.

But if the contestation happens, it will be a sequestered side and dominated one. So, when humans are isolated from the community, they believe that sometimes the truth will come at the moment (continuum of the community). This understanding comes from the distinction between reality and the truth because it is like dynamics that often appears in human interactions. ${ }^{4}$ The belief to resist will come from the individualistic view, but it is not totally challenged with the condition it will create a selfconsciousness about the appropriated situation. It is true that there is a clash among communitas, but there is also a cure for it as Esposito coins the idea of "escape of selfness" as the view of reconciliation since it will discuss the sameness of selfconsciousness that will be deconstructed by its society. ${ }^{5}$

\footnotetext{
${ }^{3}$ Quran 101: 1-5

4 Roberto Esposito, Communitas: The Origin and Destiny of Community (California: Standford University Press, 2009).

${ }^{5}$ Ibid.
} 
In the context of Java, Frans Magnis-Suseno has provided some influential idea about Javanese ethics and its world view, which has a rule of Morality and the relativity between good and evil. The Javanese morality comes from the perspective of the family, while the belief of the value derives from the development of the moral itself from their daily life. ${ }^{6}$ In this view, we can see how the development of morality affects the way of Javanese thinking, starting from the family to the condition of the community surrounding its environment. But on a particular position, it will find a "place of the relative" where the situation created from the relativity between good and evil, in which the place is situated in peaceful cosmologies. ${ }^{7}$ The position between a good and evil is often problematic because of the various worldview that will bring in every single mind, including the community rule of principle, which also has many ways of regulative thinking. So, the contestation does still exist; although there is a concept of reconciliation named rukun because the appropriated condition between the good and evil is still utopist regarding the contradictive meaning among them, the negotiated position occurs on the avoiding clash for the unexpected situation.

Different from Turner in examining the communitas, he does not blame that the human has an innate knowledge of the "genuine interactive communitas". However, with the process from infant to the adult, they will recognize the true and false, due to the interaction that they will face. The contestation between the communitas and anticommunitas assumption creates a different view to see its collective joy, so it needs to see what kind of "joy" that can be negotiated. ${ }^{8}$ Legitimation between true and false, good and evil, is the product of the human contacted with some considerations. To find its awareness of consideration, it will need the maturity of thought, in the way how many times the people meet the situation what they deserve, whether it was suitable to applicate or isolate from their life. The separation of the

${ }^{6}$ Franz Magnis-Suseno, Javanese Ethics and World-View: The Javanese Idea of the Good Life (Jakarta: Gramedia Pustaka Utama, 1997).

${ }^{7}$ Ibid.

8 Edith Turner, Communitas: The Anthropology of the Collective Joy (USA: Palgrave Macmillan, 2012). 
contrasting view construction occurs since how they contacted with the world creating the worldview based on their assumption, although human has an innate identity brought by his or her generation physically or socially.

\section{Geertz typology on pilgrimage space}

In Geertz's categorization, the Javanese typology falls into three different groups of beliefs, namely abangan, santri, and prijaji. Geertz divides the religion of Java-based on the belief and practice usually performed by the people. Recognition of mysticism, ritual, and the ideological categorization sometimes contributes to the conflict that is hard to avoid, especially between abangan and santri, rather than make contact with prijaji community. ${ }^{9}$

Recognizing the power of spirits is the main typology between abangan and santri differentiation. The engagement of some kind of Javanese spirits in their daily life is a basic belief to increase wealth, health, agriculture, and ceremony. The existence of spirits of wealth is pictured on tuyul, imagined in the three old children sprit who can gather monies for the people who believe and own this spirit. It is well-known spirits among Javanese because it can steal one's money. Many Javanese people believe that when their money lose without any reason from its place or even forgetting to put it down, they often relate the lost to the act of tuyul that stole the money. So, if one does not want to lose his/her money, he/she should put money in the Qur'an or even part of the sacred text beside it. And the other option is to put the mirror beside the money because of this children spirits like to play with a mirror. Furthermore, to get this spirit, the people come too eerie place such as the cemetery or sacred place, often found in a hill, mountain, cave or old big tree.

Lelembut or possessing spirits is also connected with the effect of health and some disease. The term sawanen is used to describe that somebody is possessed by the spirit of a dead person or even the soul of the spirits enter the body of the patients. Lelembut resides in a sacred place as the guardian of it. People should not

${ }^{9}$ Clifford Geertz, The Religion of Java (USA: University of Chicago Press, 1976). 
commit immoral practice, and impolite activity surrounded that place.

One of the local inhabitants said that one of the visitors in the Surowiti hills urinated on the trees located next to the pilgrimage place. A day later, after arriving home, he got a sudden illness and died. One of the coffee shoppers also analogized that case with an incident happening to a couple who became a stone because they did sexual intercourse surrounding the area of Sunan Giri pilgrimage, one of the most visited sacred places amongst the nine saints (Walisongo). The ethical consideration should be done on the sacred space in respecting the existence of the saint, although it was articulated on the tomb and its history of the Islamic spreading.

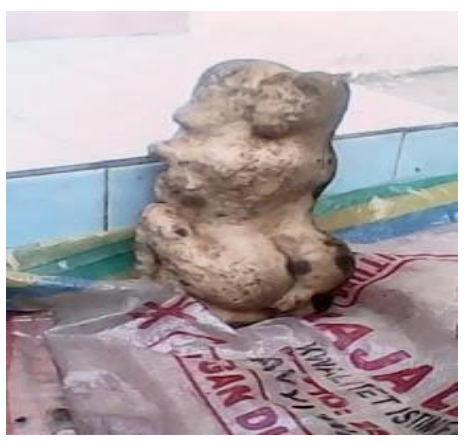

Picture 1: The statue of the hugged youth is found around the Sunan Giri's pilgrimage complex ${ }^{10}$

On the agricultural matter, the Javanese also believe in mystical spirits of Dewi Sri (goddess of landfarming and plants) in keeping the bounty of their field. Doing some ritual before and after harvesting moment is to get a good crop on their agricultural product. Moreover, they also consider about the Javanese numerological calendar when starting the planting session.

Slametan is one of the abangan rituals. It is devoted to somebody, the guardian spirit or village and is conducted in accordance with a particular time and place. According to Geertz, there are four main reasons why the Javanese should do this ritual: the crises of life, Muslim ceremonial calendar, social integration of

${ }^{10}$ Source: https://wn.com/manusia_mesum_dikutuk_menjadi_batu 
the village, and unusual occurrences. ${ }^{11}$ The centre of this ceremony is a communal feast and commemoration through allotting some food and meals to the neighbour or local inhabitants surrounding this event.

In Surowiti sacred place, it is also found the slametan practice surrounding the site. For the visitors, they will hold a slametan when their prays are accepted and answered through dividing the meals not only for the visitors but also for local inhabitants and the caretaker of the site. For the local inhabitants, when they get unusual occurrences, they also hold the slametan in this sacred place. Also, due to their respect and blessing that they have gotten, they pray on the cemetery complex. But the problem of contestation does not come from the matter of slametan; it is about who should facilitate and pray in the site in order to get a blessing. This question leads to the issues of religiosity and local identity.

\section{Javanese mystical elite vs religious elite}

In the Javanese belief, there is a person who cures disease, leads a ceremony, and help the worldly problem through some rites spell and chanting, called dukun. In Geertz's categorization of dukuns, it is not clear whether dukun was part of the practices of abangan group, santri way of life, or even just for a prijaji community. But for abangan dukun, Geertz has explained some categories of abangan dukun, for example, dukun bayi who help pregnant women in bearing bayi (baby), dukun kemanten, who work for weeding, dukun prewangan who can make a medium with a spirit, and the other dukun: dukun tjalak (circumcisions), dukun pijet (masseurs), dukun sihir (sorcerer), and dukun petungan (numerical expert). While dukun prijaji practice rituals in some ceremonial art or as a mystical teacher (guru). ${ }^{12}$

There are dukuns in sacred places which help the visitors to get what they want. Dukun prewangan mediate visitors and spirits. The dukun performs a specific ritual, such as meditation and fasting, to call for the spirit that visitors wish. Besides, they also can mediate with the spirit to win lottery and gambling or get heirlooms, such

${ }^{11}$ Geertz, The Religion of Java.

${ }^{12}$ Ibid. 
as keris (Javanese sword) and akik (stone rings). Dukun not only can be found on the location of the sacred pilgrimage site but also from the outside, who are expert in spiritual praying. Some dukun even brings their followers to come to the site to pray and do certain rituals.

Woodward argues that there are also dukuns with a santri background. Unlike others, who use the medium of spirit, the santri dukun seeks help from God. Their rituals involve the combination of praying, mediation, and traditional medicine which has existed in Java. ${ }^{13}$ Some dukuns in this landscape of the site also practised those kinds of the roles which they try to acknowledge the visitors to practice the religious chanting when they visit it. Indeed, they also command the visitors not to depend on the spirits for getting wealthy but should ask God directly. Moreover, they also give the appropriated chanting and some tools or symbols to get a blessing and respond to their praying when visiting the mausoleum such as water, stone, oil, or rajah. ${ }^{14}$

The category of dukun santri is problematic with respect to the categorization of the community since dukun mostly refers to abangan that contradicts santri both in terms of belief and ritual. The term dukun also has a contrary assumption for the santri community. Thus, it is contested by them, regarding their practice and belief which are unappropriated with the religious dogma written in the sacred text. Interestingly, there are one influential local people who disagree with the existence of the dukuns in pilgrimage space. He stated that "As one of the alumni of Islamic boarding school, I do not acquiesce in the existence of the dukuns on the Sunan Kalijaga cemetery, and their practices as well. Therefore, I try as often as possible to organize some religious agenda on the mosque surrounded the village such as isthighotsah (public and communal chanting), tahlil (Islamic slametan), and religious sermons."

This view shows how the contestation between traditional religion and institutionalized religion, in which the first focus on

${ }^{13}$ Mark R. Woodward, Java, Indonesia and Islam (USA: Springer, 2012).

${ }_{14}$ Rajah is the paper written in Arabic word and character that has supernatural power inside to cure and push away unfortunate. 
what they believe on the descended practice and the inheritance ritual. In contrast, the other one focus on the doctrinal one taught on the religious institution to legitimate between the "good" and "evil" one. But the problem is also not only on the contestation itself, but also on the community who support, believe, and refuse the existence of the practices. So, it is essential to see how the community build and rise their own perspective and worldview.

Victor Turner divided communitas into three categories pertaining to the pilgrimage discourses. Firstly, spontaneous communitas, the homogenous community which direct identities from what they have experienced. Secondly, normative communitas, the collective community established from the social control and developed from the time to find mutual consideration. Lastly, ideological communitas, the utopian society constructed from the blueprints, with the hope it can be applicated for the optimal condition. ${ }^{15}$ Turner's categorization has the way of reconciliation to see how the communitas identity raises in the pilgrimage context, where foreground of the perspective has the various kind of the community based on thinking that would be spontaneous, normative and ideological. Similarly, Robert Bellah examines religion and human evolution which are shifting from mimetic, mythical, ethical, and modern synthesis. ${ }^{16}$ In the pilgrimage context, I also examine the theory that the shifting the sense happen in the way of "religious evolution", then it is more influenced how the representation not only for the tourist but also for the local inhabitants. ${ }^{17}$ But it is less on the way the contestation and community constructed in pilgrimage space; it focuses on how the religious beliefs build in the way of 'evolution'.

In conclusion, it is better to consider the contested communitas that had been examined by Turner. He stated that "These remarks raise the important point that though pilgrimages strain, as it

${ }^{15}$ Victor Turner, “The Center out There: Pilgrim's Goal," History of Religions 12, no. 3 (1973): 191-230, www.jstor.org/stable/1062024.

16 Robert N. Bellah, Religion in Human Evolution: From the Paleolithic to the Axial Age, 1st Edition edition. (Cambridge, Mass: Belknap Press, 2011).

17 Taufiqurrohim, Shifting the Sense of Pilgrimage: Examining Petilasan Sunan Kalijaga in Surowiti Hill Gresik (Yogyakarta: Proceeding the 8th International Graduate School and Scholar Conference Universitas Gadjah Mada, 2016). 
were, in the direction of universal communitas, they are still ultimately bounded by the structure of the religious systems within which they are generated and persist."18

\section{Contestation of pilgrimage ritual (between deviant practice and appropriated practice)}

Catherine Bell, in her book "Ritual Theory, Ritual practice" explores the relationships between the ritual, belief, and ideology. She states that "the projection and embodiment of schemes in ritualization are more productively viewed as a 'mastering' of relationships of power relations within an arena that affords a negotiated appropriation of the dominant values embedded in the symbolic schemes."19 Moreover, Bell adds that the traditional association of the belief had been prisoned into the symbolic way of thinking, so it creates a challenge situation where the symbol as essential thinking of legitimation even the ritual itself competed into dissimilar ways. ${ }^{20}$

From the Bell's exploration about the ritual discourses, we can see how the contestation of the belief and society is centred on the symbolic definition from each individual and community, regarding dissimilarity of the ritual that have been bounded. In the site, it is found various aims and reasons to come to the site. A senior informant, for example, divides three categorizations of the visitors: religious spiritualism, supernaturalism, and frequent visitors. This information best describe the types of visitors.

The first category, religious spiritualism, is defined as the visitors who come to the site to seek the blessing from the religious people or has a high spirituality. So, they pray to the grave by reading religious chanting and sacred text around the site associated with one of the nine saints, namely Sunan Kalijaga. By praying in this site, this type of visitor perceives the saint as the best medium through which they ask God. The saint as mediation of visitors' hope and praying to God.

18 Turner, “The Center out There: Pilgrim's Goal."

${ }^{19}$ Catherine Bell, Ritual Theory, Ritual Practice, 1 edition. (New York: Oxford University Press, USA, 2009).

${ }^{20}$ Ibid. 
The second category refers to visitors who come to the site with the aims of supernaturalism for the sake of pesugihan, perdukunan, and other spiritualistic practices. They are looking for the supernatural power provided in the site. Sunan Kalijaga, who is often associated with this site, is historically also well-known with his spiritual power. His picture holding a keris is considered as power. The black Javanese cloth wore by him is also recognized as his power of Javanese mysticism and the real blood Javanese, while the other walisongo wear a long white dress depicting the Arab garb. The other famous history is about his spiritual power to defeat a mystical figure of Javanese saint Shaykh Siti Jenar, who represented Sufism with controversial teaching such as the union of human and God (wahdat al-wujud). Another story of this saint is concerned with his supernatural power to build the Demak mosque as the rising power in the weak of the Hindu Javanese Majapahit Kingdom.

These narratives of this power saint encouraged visitors to perform prayer in this site so they can acquire power from him. They want to gain not only for worldly matter (getting rich, success of business and work, power of beating people, and cleverness) but also for hereafter matter (getting high quality of faith, nearing of the God blessing and the right meditation based on Javanese mysticism). The visitors sometimes bring their spiritual teachers also to mediate what they pray in the cemetery.

The last category is the common visitors that want to know about the site or just fulfilling their anxiety during the trip. Enjoying the panorama, architecture, inheritance, history, and tourism is the main aims of why they come to the site. So, the rituals that they do are just walk around the site to look at what the site provides and follow the activities suggested by the management of the site.

The categorization of the visitors points out how they distinguish among the community on their ritual to get their aims. For the first religious background, the ritual is considered by their ritual of praying to God through doctrinal legitimation. The ritual of the supernatural is through mystical practice such as bringing flower and incense during their pilgrim. But the differentiation of the view does not stop with that role; it also occurs in the time of 
the visitors. One of the residents explained that the "difference between of visitors on Friday night legi or kilwon, ${ }^{21}$ Monday or Thursday indicate their aims of the visit to the cemetery." Friday night is assumed as the Javanese mystics day for praying and doing some supernatural power, while Monday and Thursday as the day when the Sunan Kalijaga cemetery is opened. The weekend is the favourite common visitors.

The contestation also happens in the method of the ritual. While the religious visitors chant and recite the sacred text as loud as possible, sometimes they bring a loudspeaker, the supernatural spiritualistic visitors perform meditation and use a silent method. Not surprisingly, each may compete with each other; they come to the same site but with a different motives and spiritual practice. Accordingly, the common visitors assume it as the disturbance of the sacred of the site. They maintain that the place must be free from commotion and noisy so visitors can feel calm at the site.

A specific difference in the ritualistic aspect of the practices among abangan and santri is identified. The first focuses on the detail of the ritual, while the latter is on the doctrine or normativity of ritual in Islam. ${ }^{22}$ The general difference is regarding the matter of the social organization, the way of ideological perspective constructed on the individualistic household while santri is crystallized by the concept of the ummah (community). ${ }^{23} \mathrm{In}$ addition, Geertz also divides santri into modern and old-fashioned categorization, which it also influences the way they respond to the existence of abangan practices.

Nelly van Dorn also examines the role of modernist Islam (Muhammdiyah) and traditionalist one (Nahdlatul Ulama/NU). The modernist puritans disagree with visiting and praying at the graveyard (ziarah) since it is assumed as the Hindu practice descended from the ancestor. The practice should be, therefore rejected. They promote Islamic teaching based on the sacred text

${ }^{21}$ In Javanese alphabetically circle of the day calendar, they are pon, pahing wage, legi and kliwon and these are circulated as the sign of the day in Javanese periodical calendar.

${ }^{22}$ Geertz, The Religion of Java.

${ }^{23} \mathrm{Ibid}$. 
and hadith. ${ }^{24}$ But the contestation does not merely apply on the modernist-traditionalist divide, but also on the specific ritual that should be practised in the pilgrimage space.

\section{Contestation for the visitor gaze: Finding a various spirituality and consuming a sacred site}

John Urry's theory explains that tourist gaze expresses the dynamics associated with the construction of tourist experience, the complexity of the social organization of tourism, and the systematic nature of these processes. It allows us to articulate what separates tourist experience from everyday living in which production and consumption of tourist goods and services have broad implications for social relations. The social organization of these processes encompasses a number of elements, including carefully chosen images about places to see, narratives that speak about the uniqueness of their history, culture and heritage, varieties of performative practices through which tourist experiences are embodied, and a network of professionals and institutions providing services to ensure that particular tourist experiences can be generated. These developments are closely related to attract mass tourism, consumerism, and commodification of places and cultural practices. The gaze is an organizing principle which structures encounter among tourists and people and places visited at multiple levels. It helps to create an experience that is felt as extraordinary and memorable and also implicates people into a systematic set of social relations through competition for tourist attention.

From the theory of tourist gaze, we can see when the people go out from their usual activity in finding the environment to fill their interest and curiosity. That is the case pointed out by John Urry. The visitors absolutely have gaze about what they want to see in visiting the place. But the form of the gazes can be found in

24 Nelly Doorn-Harder and Kees Jong, "The Pilgrimage to Tembayat: Tradition and Revival in Indonesian Islam," Muslim World 91 (September 1, 2001): 325-354. 
romantic gazed -initiated with the privacy, latitude, and semispiritual relationship or in the collective gaze. ${ }^{25}$

There is an important point that can be underlined by one of the spiritual teachers, Ngadiyono (40), to see the phenomena of the pilgrim happened in this contested site. He differentiates between ghayb (invisible), mystic and magic. He explains that there are so many hypocritical people with what they believe, see, and practice. When they believe in Allah, they should also believe that God is also invisible. It is same with the aims of the people to live in this world to seek happiness as an abstract quality. The people who do not believe those roles is also to blame their selves to what they practice.

The communication that we do to get those invisible aims and beings is categorized as a mystical one. The methods by praying, meditating, or chanting indicate the personal mystical belief that used by them in getting those purpose in God as the highest aims to what they deserve, but the method is also various that used magic or just through that mystical way. The magic explicated on some mystical beings cannot be tolerated. The practice, according to Islamic doctrine, is categorized into shirik (polytheism) because the practitioners do believe in God's power.

At this last point of the ideological contestation, I would take the Turner conclusion in his book communitas, where he states that "nothing humans to be aliens for me. We respond to the energy and caps for a better future generation; even it will be contested by our grand-children with the existing computer technologies". ${ }^{26}$ The process of the contestation in nowadays is also a product of the response to the people interact to what already existed in contemporary life.

\section{Conclusion}

Ideological conflict is rooted from the various identity bound in the Javanese society by which the categorization of the religion of Java by Geertz is so helpful as the analysis tool. The idea of

${ }^{25}$ John Urry and Jonas Larsen, The Tourist Gaze 3.0: Theory, Culture and Society (London: SAGE Publications, 2011).

${ }^{26}$ Turner, Communitas. 
communitas and contestation articulated as the grassroots explains why the idea is challenged to each other. The existence of some dukun in the surrounding sites raises question and pros and cons amongst visitors as well as residents. The disputes revolve around the method of ritual and the ideology that underpins it.

The contestation of the pilgrimage or tourism site is not merely about sacred and profane or secular, but it also about the broader explanation of how the ideology of the community building as the primary view of the anti communitas regarding the different foreground and root of beliefs. The explanation of managerial and representational of pesugihan site give nuance of the contestation build from the context rather than to see the academical and conceptual contestation.

\section{References}

Bell, Catherine. Ritual Theory, Ritual Practice. 1 edition. New York: Oxford University Press, USA, 2009.

Bellah, Robert N. Religion in Human Evolution: From the Paleolithic to the Axial Age. 1st Edition edition. Cambridge, Mass: Belknap Press, 2011.

Doorn-Harder, Nelly, and Kees Jong. "The Pilgrimage to Tembayat: Tradition and Revival in Indonesian Islam." Muslim World 91 (September 1, 2001): 325-354.

Esposito, Roberto. Communitas: The Origin and Destiny of Community. California: Standford University Press, 2009.

Geertz, Clifford. The Religion of Java. USA: University of Chicago Press, 1976.

Goodman, Paul, and Percival Goodman. Communitas: Means of Livelihood and Ways of Life. New York: Random House Vintage Book, 1960.

Magnis-Suseno, Franz. Javanese Ethics and World-View: The Javanese Idea of the Good Life. Jakarta: Gramedia Pustaka Utama, 1997.

Taufiqurrohim. Shifting the Sense of Pilgrimage: Examining Petilasan Sunan Kalijaga in Surowiti Hill Gresik. Yogyakarta: Proceeding the 8th International Graduate School and Scholar Conference Universitas Gadjah Mada, 2016. 
Turner, Edith. Communitas: The Anthropology of the Collective Joy. USA: Palgrave Macmillan, 2012.

Turner, Victor. “The Center out There: Pilgrim's Goal." History of Religions 12, no. 3 (1973): $191-230$. www.jstor.org/stable/1062024.

Urry, John, and Jonas Larsen. The Tourist Gaze 3.0: Theory, Culture and Society. London: SAGE Publications, 2011.

Woodward, Mark R. Java, Indonesia and Islam. USA: Springer, 2012. 